\title{
MENINGKATKAN HASIL BELAJAR PPKN MELALUI MODEL PEMBELAJARAN TGT (TEAM GAMES TOURNAMENT) SISWA KELAS 5 SD NEGERI 164525 TEBING TINGGI
}

\author{
Siti Era Harahap \\ Surel: ibusitieraharahap@gmail.com
}

\begin{abstract}
ABSTRAK
Tujuan dari penelitian ini adalah untuk meningkatkan hasil belajar PPKN Kelas 5 SD Negeri 164525 Tebing Tinggi tahun pelajaran 2017/2018 melalui model pembelajaran kooperatif Team Games Tournament. Penelitian tindakan kelas ini menggunakan model Kemmis M Taggart. Penelitian ini dilaksanakan sebanyak 2 siklus. Subjek pada penelitian ini adalah siswa kelas 5 SD Negeri 164525 Tebing Tinggi. Pelajaran dengan model TGT pada materi pelajaran PPKN di kelas 5 SD Negeri 164525 Tebing Tinggi memiliki dampak positif dalam meningkatkan hasil belajarsiswa yang ditandai dengan peningkatan ketuntasan belajar siswa dalam setiap siklus, yaitu siklus I $(53,33 \%)$, siklus II $(93,33 \%)$ dan dinyatakan berhasil.
\end{abstract}

Kata Kunci: Hasil Belajar, PPKN, Model TGT (Team Games Tournament)

\section{PENDAHULUAN}

Pendidikan Pancasila dan kewarganegaraan (PPKN) perlu diajarkan kepada siswa sejak sekolah dasar (SD) agar siswa mendapat pelajaran tentang pentingnya moral, sikap dan tingkah laku yang menunjukkan dirinya masyarakat Indonesia, nilai-nilai, hak dan kewajiban agar setiap warga Negara memiliki tujuan dan pengetahuan yang sama tentang identitas Negara. Siswa sekolah dasar (SD) harus ditanamkan jiwa nasional sehingga ke depan siswa memahami makna dari tujuan dan cita-cita Negara Indonesia dengan cara mengenali atau mengetahui identitas negaranya sendiri. Selain itu sesuai dengan tujuan pendidikan nasional, pendidikan kewarganegaraan bertujuan untuk meningkatkan kualitas masyarakat Indonesia yang berbudi luhur, berkepribadian Indonesia yang baik, mandiri, tangguh, profesional, bertanggung jawab, dan produktif serta sehat jasmani dan rohani.

Jika dapat menguasai pendidikan kewarganegaraan warga Negara dapat mengembangkan kemampuan-kemampuan sebagai berikut:

a. Berpikir secara kritis, rasional dan kreatif dalam menghadapi berbagai masalah kewarganegaraan.

b. Berpartisipasi secara aktif dan bertanggungjawab, serta bertindak secara cerdas dan 
Siti Era Harahap: Meningkatkan Hasil Belajar ..

kegiatan bermasyarakat, berbangsa dan bernegara.

c. Berkembang secara positif dan demokratis untuk membentuk diri berdasarkan pada karakterkarakter masyarakat Indonesia agar dapat hidup secara berdampingan dengan sessama.

Berinteraksi dengan bangsabangsa lain dalam percaturan dunia secara langsung atau tidak langsung dengan memanfaatkan teknologi informasi dan komunikasi

Pada kenyataannya, PPKN dianggap ilmu yang sukar dan sulit dipahami. Begitu luasnya materi PPKN menyebabkab anak sulit untuk diajak berfikir kritis dan kreatif dalam menyikapi masalah yang berbeda. Sementara anak usia sekolah dasar tahap berfikir mereka masih belum formal, apa yang dianggap logis, jelas dan dapat dipelajari bagi orang dewasa, kadang-kadang merupakan hal yang tidak masuk akal dan membingungkan bagi siswa. Akibatnya banyak siswa yang tidak memahami konsep PPKN.

Dalam melaksanakan tugas di lapangan peneliti sebagai guru kelas SD Negeri 164525 masih banyak menemui berbagai kendala. Rendahnya pencapaian nilai akhir siswa disebabkan karena faktor guru dan faktor siswa. Dalam proses kegiatan belajar-menggajar guru kurang bervariasi dalam menggunakan model pembelajaran.
Rendahnya hasil belajar siswa menjadi indikasi bahwa pembelajaran yang dilakukan selama ini belum efektif. Untuk memperbaiki hal tersebut perlu disusun suatu model pembelajaran yang dapat mengaitkan materi teori dengan kenyataan yang ada dilingkungan sekitarnya yaitu dengan menggunakan model pembelajaran kooperatif tipe TGT.

$$
\text { Menghadapi kenyataan }
$$

tersebut di atas, penulis tertarik untuk mendalami dan melakukan tindakantindakan perbaikan pembelajaran PPKN, melalui penelitian tindakan kelas. Berdasarkan latar belakang dan identifikasai masalah di atas, rumusan masalah pada penelitian ini adalah apakah hasil belajar siswa kelas 5 SD Negeri 164525 Tebing Tinggi dapat meningkat melalui penerapan model pembelajaran TGT (Team Games Tournament)?

Tujuan dari penelitian ini adalah untuk meningkatkan hasil belajar PPKN melalui model pembelajaran TGT pada siswa kelas 5 SD Negeri 164525 kota Tebing Tinggi tahun pelajaran 2017/2018. Sedangkan manfaat penelitian ini adalah sebagai berikut :

a. Bagi siswa karena dapat meningkatkan hasil belajar PPKN model pembelajaran TGT pada siswa kelas 5 SD Negeri 164525 Tebing Tinggi.

b. Bagi guru Meningkatkan kualitas guru dalam melaksanakan tugas mengajar terutama dalam mengajar PPKN. 
c. Bagi sekolah sebagai masukan dalam upaya perbaikan pembelajaran.

Hasil belajar adalah perubahan tingkah laku yang terjadi pada diri individu yang mengikuti proses pembelajaran yang mencakup aspek kognitif, afektif dan psikomotorik.Aktivitas belajar dengan permainan yang dirancang dalam pembelajaran kooperatif model TGT memungkinkan siswa dapat belajar lebih rileks disamping menumbuhkan tanggung jawab, kerjasama, persaingan sehat dan keterlibatan belajar. Dalam penelitian ini hasil belajar pada pelajaran PPKN diukur melalui tes formatif dengan KKM 70.Bagi siswa yang nilainya kurang dari 70 diberi soal perbaikan dan bagi siswa yang nilainya $70 \mathrm{ke}$ atas diberi soal pengayaan dalam bentuk pekerjaan rumah.

Teknik kooperatif learning model TGT ini dikemas dalam bentuk permainan karena bermain merupakan pemenuhan suatu kebutuhan mendasar bagi anak-anak serta sesuatu yang sangat menarik. Melalui model TGT siswa diajak untuk belajar memecahkan masalah dengan bantuan kelompok sosial yang anggotanya temantemannya sendiri.

Adapun langkah-langkah kegiatan pembelajaran tipe TGT adalah sebagai berikut:

a. Penyajian Kelas
Pada saat penyajian kelas ini siswa harus benar-benar memperhatikan dan memahami materi yang disampaikan guru, karena akan membantu siswa bekerja lebih baik pada saat kerja kelompok dan pada saat game karena skor game akan menentukan skor kelompok.

b. Kelompok (Team)

Fungsi kelompok adalah untuk lebih mendalami materi bersama teman kelompoknya dan lebih khusus untuk mempersiapkan anggota kelompok agar bekerja dengan baik dan optimal pada saat game.

c. Game

Game terdiri dari pertanyaanpertanyaan sederhana bernomor yang dirancang untuk menguji pengetahuan yang didapat siswa dari penyajian kelas dan belajar kelompok.

d. Turnamen

Biasanya turnamen dilakukan pada akhir mingggu atau pada setiap unit setelah guru melakukan presentasi kelas dan kelompok sudah mengerjakan lembar kerja.

e. Penghargaan Kalompok

Masing-masing team akan mendapat sertifikat atau hadiah apabila rata-rata skor memenuhi kriteria yang ditentukan. 
Siti Era Harahap: Meningkatkan Hasil Belajar ..

Tujuan dari penggunaan model Team Games Tournament ini adalah sebagai berikut:

a. Untuk motivasi siswa.

b. Untuk menarik minat dan perhatian siswa.

c. Memberikan kesempatan kepada siswa untuk mengeksplorasi situasi dimana mereka mengalami emosi, perbedaan pendapat, dan permasalahan dalam lingkungan kehidupan social anak.

d. Menarik siswa untuk bertanya.

e. Mengembangkan kemampuan komunikasi siswa.

f. Melatih siswa untuk berperan aktif dalam kehidupan nyata.

Hal penting dalam model pembelajaran TGT adalah keterlibatan siswa untuk berpartisipasi dalam situasi atau masalah nyata serta adanya keinginan untuk mengatasi suatu masalah bersama. Pemahaman siswa dalam model bermain peran dapat memberikan contoh pada siswa dalam kehidupan sehari-hari untuk berperilaku sebagai berikut:

a. Menjajagi perasaan.

b. Menambah pengetahuan tentang sikap, nilai-nilai dan persepsinya.

c. Mengembangkan keterampilan berkompetisi dalam kehidupan nyata

d. Mengkaji pelajaran dengan berbagai cara.
Dengan menggunakan model pembelajaran Kooperatif TGT siswa diharapkan dapat bekerjasama, saling membantu mengembangkan potensi diri secara optimal bagi kelompoknya dan belajar memperoleh dan memahami pengetahuan dan berkompetisi dengan jujur, adil secara langsung, serta melibatkan siswa aktif dalam mengembangkan pengetahuan, sikap, keterampilan dalam suasana belajar yang menyenangkan mereka, sehingga apa yang dipelajari lebih bermakna dan dipahami bagi diri setiap siswa.

\section{METODE PENELITIAN}

Penelitian ini bertempat di SD Negeri 164525 terletak di Jl. Soekarno Hatta Kelurahan Tambangan, Kecamatan Padang Hilir kota, Kota Tebing Tinggi. Subyek penelitian adalah siswa-siswi Kelas 5 SD Negeri 164525 kotaTebing Tinggi Tahun Pelajaran 2017/2018. berjumlah 30 orang.

Waktu penelitian ini dilaksanakan dari bulan Agustus sampai dengan Oktober 2017 dengan prosedur penelitian yang digunakan adalah penelitian tindakan kelas yangterdiri dari 2 siklus dengan menggunakan model penelitian tindakan dari Kemmis Mc Taggart yang dikemukakan Hopkins (Zainal Aqib, 2006) yaitu berbentuk spiral dari siklus yang satu ke siklus yang 
berikutnya. Setiap siklus meliputi planning (rencana), action (tindakan), observation (pengamatan), dan reflection (refleksi). Langkah pada siklus berikutnya adalah perncanaan yang sudah direvisi, tindakan, pengamatan, dan refleksi.Sebelum masuk pada siklus 1 dilakukan tindakan pendahuluan yang berupa identifikasi permasalahan.

Pada tahap implementasi pelaksanaan tindakan ini guru melakukan pelajaran di dalam kelas dengan menggunakan panduan perencanaan yang telah dibuat. Suasana masing-masing kelompok di kelas dikondisikan agar tidak terlalu formal, maksudnya siswa bebas mengemukakan pendapatnya tentang materi ajar sesuai dengan kompetensi dasar yang ingin dicapai. Siswa berinteraksi kepada guru secara langsung, bebas, sesuai kondisi nyata dan menyenangkan.

Instrumen dalam penelitian ini adalah tes hasil belajar yang dilaksanakan setiap akhir siklus. Tes berbentuk tes uraian yang bertujuan untuk mengetahui ketuntasan belajar siswa secara individual maupun secara klasikal. Disamping itu untuk mengetahui letak kesalahan-kesalahan yang dilakukan siswa sehingga dapat dilihat dimana kelemahannya, khususnya pada materi ajar yang belum tercapai.

Untuk memperkuat data yang dikumpulkan, maka juga digunakan observasi (pengamatan) yang dilakukan oleh teman sejawat untuk mengetahui dan merekam aktifitas guru dan siswa dalam proses belajar mengajar.

Pada penelitian ini menggunakan teknik analisis dekriptif kualitatif, yaitu suatu metode penelitian yang bersifat menggambarkan kenyataan atau fakta sesuai dengan data yang diperoleh dengan tujuan untuk mengetahui pemahaman yang dicapai siswa, juga untuk memperoleh respon siswa terhadap kegiatan pelajaran serta aktivitas siswa selama proses pelajaran.

Penelitian ini dapat dikatakan berhasil dan tidak perlu dilanjutkan kepada siklus berikutnya apabila hasil dari tes siswa yang berjumlah 30 orang telah sesuai dengan KKM yang ditentukan yaitu 70 atau tingkat ketuntasan kelas diatas $85 \%$ dari 30 siswa. Selain itu jika dilihat dari pengelolaan pelajaran, yaitu persentase pengelolaan pelajaran yaitu aktivitas guru dan aktivitas siswa diatas $85 \%$.

\section{HASIL DAN PEMBAHASAN}

Sebelum penelitian dilakukan, terlebih dahulu peneliti mengadakan survei pra siklus pada minggu sebelumnya. Peneliti mengidentifikasi masalah melalui pengamatan proses belajar mengajar yakni rendahnya hasil belajar siswa pada kelas 5 SD 
Siti Era Harahap: Meningkatkan Hasil Belajar ..

Negeri 164525 Tebing Tinggi mata pelajaran PKN. Kegiatan ini dilakukan dengan tujuan menyampaikan maksud mengadakan penelitian tindakan kelas dengan menerapkan model pembelajaran kooperatif tipe TGT (Team Games Tournament) untuk meningkatkan aktivitas siswa dalam proses pembelajaran. Pada pengamatan dilakukan dengan menggunakan lembar observasi aktivitas siswa dan menggunakan penilaian hasil evaluasi melalui ulangan harian. Jumlah siswa yang lulus pada hasil evaluasi yang dilakukan adalah sebanyak 5 siswa memenuhi kriteria nilai KKM dari 30 siswa.

Hasil temuan penelitian tindakan kelas dengan menggunakan model pembelajaran kooperatif tipe TGT pada siklus I yang dilaksanakan pada tanggal 23 Agustus 2017 di kelas 5 SD Negeri 164525 Tebing Tinggi mengalami peningkatan nilai ketuntasan siswa dari 5 orang menjadi 16 orang.

Berdasarkan rumus ketuntasan belajar siswa secara klasikal diperoleh:

$\mathrm{PKK}=\frac{16}{30} x 100 \%=53,33 \%$.

Dari tes hasil belajar pada siklus I tersebut maka dapat diketahui dari 30 orang siswa terdapat sebanyak 16 orang siswa $(53,33 \%)$ mendapat nilai tuntas dan sebanyak 14 orang siswa $(46,66 \%)$ mendapat nilai tidak tuntas. Selain itu juga dilakukan observasi terhadap aktivitas belajar siswa. Hasil tes ulangan harian siklus I dapat dilihat pada grafik berikut:

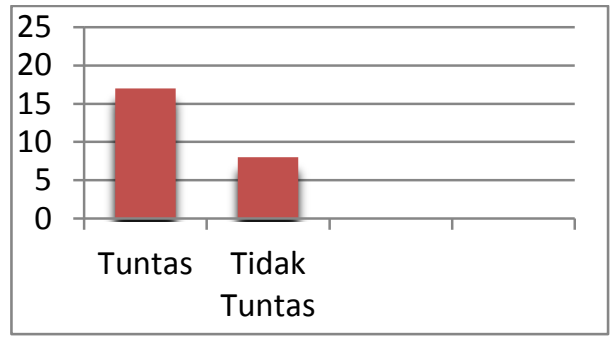

Gambar 1. Grafik Hasil Belajar Siklus I

Dapat dijelaskan hasil belajar siswa pada siklus I bahwa dengan menerapkan model pembelajaran kooperatif tipe TGT pada materi pelajaran diperoleh ketuntasan belajar mencapai $83,33 \%$ atau ada 16 siswa dari 30 siswa sudah tuntas belajar. Hasil tersebut menunjukkan bahwa pada siklus pertama secara klasikal siswa belum tuntas belajar, karena siswa yang memperoleh nilai $\geq 70$ hanya sebesar $83,33 \%$ lebih kecil dari persentase ketuntasan yang dikehendaki yaitu sebesar $85 \%$. Namun dibandingkan dengan siklus sebelumnya, terjadi peningkatan hasil belajar siswa. Maka dari itu, dilanjutkan ke siklus II.

Pelaksanaan kegiatan belajar mengajar untuk siklus II dilaksanakan pada tanggal 6 September 2017 dengan jumlah siswa 30 siswa. Dalam hal ini peneliti bertindak sebagai guru. Adapun proses belajar mengajar mengacu pada rencana 
pelajaran dengan memperhatikan revisi pada siklus II, sehingga kesalahan atau kekurangan pada siklus I tidak terulang lagi pada siklus II. Pada akhir proses belajar mengajar siswa diberi tes ulangan harian II. Instrumen yang digunakan adalah tes ulangan harian II. Dapat dilihat aspek-aspek yang diamati pada siklus II yang dilaksanakan oleh guru dengan menerapkan metode pembelajaran bermain peran mendapatkan penilaian baik dari pengamat adalah mempresentasikan langkah-langkah metode pembelajaran bermain perandan membimbing siswa melakukan kegiatan. Penyempurnaan aspekaspek diatas dalam menerapkan metode pembelajaran bermain peran dengan meninjau ulang telah berhasil semaksimal mungkin.

Dari tabel di atas dapat dilihat secara garis besar kegiatan belajar mengajar dengan model pembelajaran TGT dilaksanakan sudah sangat baik. Hal ini dapat disimpulkan bahwa hasil pengamatan terhadap aktivitas siswa dalam pembelajaran mengalami peningkatan dibanding pada siklus I. Aktivitas belajar siswa tergolong kategori sangat tinggi yaitu dengan nilai rata-rata 3,6 dengan demikian maka guru tidak perlu melanjutkan pada siklus selanjutnya.

Dari hasil tindakan diperoleh bahwa pada siklus II sebanyak 30 orang siswa sebanyak 28 orang siswa
93,33\% mendapat nilai tuntas dan sebanyak 2 orang siswa $6,66 \%$ belum mendapat nilai tuntas dengan rata-rata nilai 87 . Itu artinya hasil belajar siswa sudah mencapai tingkat ketuntasan yang telah ditetapkan. Oleh karenanya peneliti tidak perlu melakukan tindakan pada siklus selanjutnya.

Adanya peningkatan hasil belajar pada siklus II dapat dilihat pada grafik berikut:

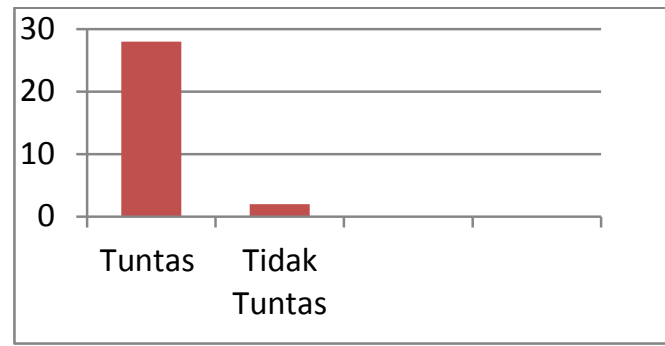

Gambar 2. Grafik Tes Hasil Belajar Siklus II

\section{Pembahasan}

Dari hasil penelitian yang diperoleh melalui kegiatan belajar mengajar yang dilaksanakan sebanyak 2 siklus yang dilakukan dengan menggunakan tes dan observasi aktivitas siswa dan guru dalam pembelajaran maka dapat dinyatakan bahwa model pembelajaran TGT (Team Games Tournament) dalam mata pelajaran PKn mengalami peningkatan, hal ini terlihat dari hasil belajar siswa yang tuntas sebesar $83,33 \%$ pada siklus I meningkat menjadi 93,33 \% pada siklus II. Hal ini dimungkinkan karena model pembelajaran TGT membuat siswa 
menjadi aktif dalam kegiatan belajar khususnya di kelas 5 SD yang memang masih mengutamakan aktivitas bermain dalam kegiatannya.

Dari hasil tes ini dapat dilihat bahwa hasil belajar dengan menggunakan model pembelajaran kooperatif tipe TGT telah mampu meningkatkan hasil belajar pada mata pelajaran PPKN sesuai dengan indikator yang telah ditentukan sehingga tidak perlu lagi dilanjutkan pada siklus berikutnya dan dikatakan berhasil.

\section{SIMPULAN}

Dari hasil temuan penelitian tentang hasil belajar siswa dengan model pembelajaran kooperatif tipe TGTdi kelas 5 SD Negeri 164525 Tebing Tinggi tahun pelajaran 2016/2017 berdampak positif dalam meningkatkan hasil belajar siswa. Hal tersebut dapat dilihat dari peningkatan persentase ketuntasan belajar siswa pada pra siklus $(16,67 \%)$, siklus I $(83,33 \%)$, dan siklus II $(93,33 \%)$.

Aktivitas siswa dalam proses pembelajaran dengan menggunakan model pembelajaran kooperatif tipe TGT juga berjalan maksimal.

\section{DAFTAR RUJUKAN}

Arikunto, Suharsimi. 2011. Penelitian Tindakan Kelas. Jakarta: Bumi Aksara.
Aqib, Zainal. 2006. Penelitian Tindakan Kelas. Bandung: Yrama Widya.

Darmadi Hamid. 2010. Kemampuan Dasar Mengajar. Bandung: ALFABETA.

Depdiknas. 2007. Pedoman Pengembangan Silabus dan Model Pembelajaran. Buku IV. Jakarta: Dikmenum Depdiknas.

Depdiknas, 2005. UU Sisdiknas No. 20 Tahun 2003. Jakarta: Depdiknas.

Dra. Dyah Sriwilujeng, M.Pd, Buku PKn untuk SD Kelas V, Jakarta: Esis.

Gatot, Muhsetyo, Drs. M.Sc, dkk, 2007, Pembelajaran PKN, Jakarta, UniversitasTerbuka.

Hisnu Tanty. 2008. Ilmu Pengetahuan Sosial IV. Jakarta: Departemen Pendidikan Nasional.

Khoiru Ahmadi, Lif. 2011. Strategi Pembelajaran Sekolah Terpadu. Jakarta: Prestasi Pustaka.

Kunandar. 2011. Penelitian Tindakan kelas. Jakarta: Rajagrafindo.

Muhibbinsyah. 2010. Psikologi Pendidikan. Bandung: Remaja Rosdakarya.

Purwanto. 2011. Evaluasi Hasil Belajar. Yogyakarta: Pustaka Pelajar. 
Slameto. 2010. Belajar dan FaktorFaktor Yang Mempengaruhinya. Jakarta: Rineka Cipta.

Slavin, Robert E. 2005.Pembelajaran Kooperatif. Alih bahasa: Mohamad Nur,dkk.
Surabaya: Pusat Sains dan Matematika sekolah UNESA.

Sudjana Nana. 2010. Penilaian Hasil Proses Belajar Mengajar. Bandung: Remaja Rosdakarya 